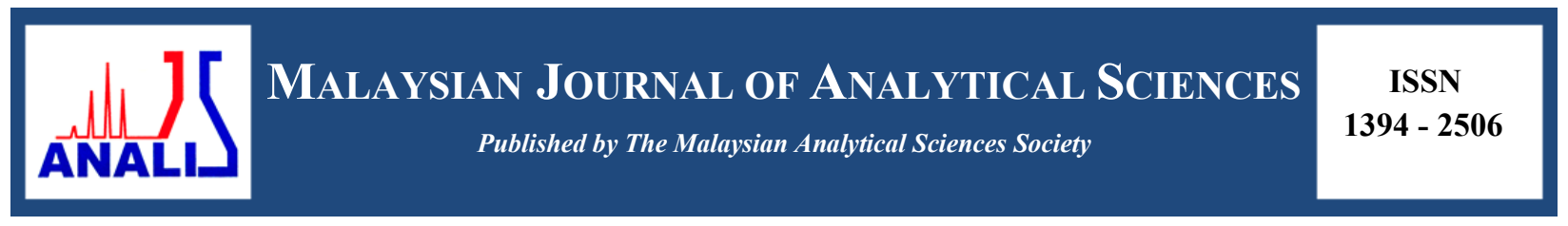

\title{
DETECTION OF BIOMOLECULES BY A NOVEL FLUORESCENCE APTASENSOR BASED ON POLYDOPAMINE SPHERES
}

\section{(Pengesanan Biomolekul oleh Aptasensor Pendarfluor Novel Berasaskan Sfera Polidopamina)}

\author{
Haiyan $\mathrm{Li}^{1}$ and Sam Fong Yau $\mathrm{Li}^{1,2 *}$ \\ ${ }^{1}$ Department of Chemistry, \\ National University of Singapore, 3 Science Drive 3, Singapore 117543, Singapore \\ ${ }^{2}$ NUS Environmental Research Institute, \\ 5A Engineering Drive 1, T-Lab Building, Singapore 117411, Singapore \\ *Corresponding author: chmlifys@nus.edu.sg
}

Received: 7 November 2016; Accepted: 18 September 2017

\begin{abstract}
Aptamers are alternative bio-recognition elements to antibodies, with great advantages, such as high binding affinity and specificity, controllable structures. In this study, a novel fluorescent aptasensor for biomolecules detection has been designed by using aptamer as bio-recognition element and polydopamines as nanoquencher. Bovine catalase protein (BCP) was used as target for assay validation. BCP aptamer was selected based on previous work in our group. Polydopamine spheres (250 - 300 $\mathrm{nm}$ ) were synthesized by addition of dopamine hydrochloride into a mixture of tris-buffer and isopropyl alcohol with stirring for more than 2 days and size/morphology of spheres has been characterized. The quenching efficiency and sensing performance were examined. It was found that the quenching efficiency was good $(>90 \%)$ owing to the interaction between aptamer and polydopamines since FAM labeled ssDNA aptamer could be adsorbed onto polydopamines surface to form a complex, resulting in the quenching of fluorescence. Upon the introduction of $\mathrm{BCP}$, the fluorescence could be retained. The fluorescence intensity increased with the increasing concentration of BCP with the detection limit of $10 \mathrm{nM}$. Polydopamines could be used as sensing platform in fast and simple way for biomolecules detection and have potential to be extended to other targets.
\end{abstract}

Keywords: biosensors, aptamer, polydopamine, nanoquencher, protein

\begin{abstract}
Abstrak
Aptamer adalah elemen alternatif pengecaman-bio terhadap antibodi, dengan kelebihan seperti ikatan keafinan yang kuat dan khusus, kebolehkawalan struktur. Dalam kajian ini, aptasensor pendarflour novel untuk pengesanan biomolekul telah di reka bentuk dengan mengunakan aptameter sebagai elemen pengecaman-bio dan polidopamina sebagai nanoquencher. Protein katalase Bovin (BCP) telah digunakan sebagai sasaran bagi ujian validasi. Aptameter BCP telah dipilih berdasarkan kerja terdahulu. Sfera polidopamina $(250-300 \mathrm{~nm})$ telah di sistesis melalui penambahan dopamina hidroklorik ke dalam campuran penimbal-tris dan alkohol isopropil dengan pengacauan melebihi 2 hari dan saiz/morfologi juga telah dicirikan. Keberkesanan pemelindapan dan prestasi sensor telah dikaji. Ia di dapati bahawa keberkesanan pemelindapan adalah baik ( $>90 \%)$ terhadap interaksi antara aptameter dan polidopamina di ketahui bahawa aptamer ssDNA berlabel FAM berupaya menyerap ke dalam permukaan polidopamina untuk membentuk kompleks, menghasilkan pemelindapan pendarfluor. Apabila BCP didedahkan, sifat pendafluor dapat dikekalkan. Keamatan pendafluor meningkat seiring dengan peningkatan kepekatan BCP pada had pengesan ialah $10 \mathrm{nM}$. Polidopamina boleh digunakan sebagai platfom sensor yang pantas dan mudah bagi pegesanan biomolekul dan berpotensi untuk dikembangkan bagi sasaran lain.
\end{abstract}

Kata kunci: sensor-bio, aptamer, polidopamina, nanoquencher, protein 


\section{Li \& Li: DETECTION OF BIOMOLECULES BY A NOVEL FLUORESCENCE APTASENSOR BASED ON POLYDOPAMINE SPHERES}

\section{Introduction}

Detection of biomolecules (biotoxins, proteins) with simple, fast, cost-effective and sensitive assay is crucial to the identification of disease-causing pathogens and water or food contamination, as well as other activities. Challenges remain in accurate and comprehensive detection and quantification of these compounds in short time at low concentrations in complex samples. Catalase is a common acidic protein that can be found in various species and is responsible for the conversion of hydrogen peroxide into water and carbon dioxide [1]. Catalase is identified as a possible bio-indicator of mastitis disease in cattle and could be used to monitor the quality of the milk.

A sensor is a device that transforms chemical or biological information, ranging from the concentration of a specific sample component to total composition analysis, into an analytically useful signal [2]. Bio-recognition elements are the important part for application of biosensors. Aptamers are special nucleic acid sequences that can bind to a wide range of targets, such as proteins, organic molecules, various cell surface receptors, and whole cells. They can be used as alternative bio-recognition elements to antibodies, with great advantages, such as high binding affinity and specificity, controllable structures and stability. Hence aptamers can be an ideal bioreceptor for the detection of biomolecules in environment, food or clinical samples. Biosensor with aptamers as ligands could be called as aptasensor. Conventional methods, such as chromatography-based and MS-based assays, are time consuming, labour intensive and not able to support on site detection. Compared to conventional methods, aptamer based biosensor can offer a sensing platform for fast disease screening and biotoxin monitoring for food and water safety.

Among different transducing systems, fluorescence is a highly sensitive platform for biomolecular detection. Nanomaterials could be used as novel biosensing platforms because of their unique optical, electronic, and catalytic properties [3]. It has been reported that some kind of nanostructures like gold nanoparticles (AuNPs), single-walled carbon nanotubes (SWCNTs), graphene oxide (GO), carbon nanoparticles and polydopamines (PDAs) can quench fluorescent dyes at different emission frequencies, which could eliminate the selection issue of fluorophorequencher pair in such assay [4-10]. It is demonstrated that PDAs would quench the fluorescence of those fluorophores due to fluorescence resonance energy transfer (FRET) $[8,9]$. Furthermore, the monomer dopamine and its oxide quinone, have shown quenching ability towards fluorophores via photoinduced electron transfer (PET) [11]. Polydopamine is a biopolymer which presents excellent biocompatibility and low cytotoxicity since it could be biodegraded in the organism through metabolism [12], which facility its application on biomolecules detection.

In the present work, a fluorescence aptasensor has been developed by taking advantage of specific aptamer and polydopamine sensing platform which is based on the fluorescence recovery due to target recognition. Bovine catalase protein (BCP) was used as target since some biotoxins are under higher biosafety control and $\mathrm{BCP}$ can be used as simulant of protein toxins for assay development. BCP aptamer was selected based on previous work in our group [13]. The quenching efficiency of polydopamine was studied and employed for the development of quenching based aptasensing platform.

\section{Reagents and materials}

\section{Materials and Methods}

Dopamine hydrochloride and bovine catalase protein were purchased from Sigma Aldrich (Singapore). FAM dyelabelled ssDNA aptamer (FAM-Aptamer, listed below) ligand of sequence was purchased from Integrated DNA Technologies Pte Ltd (IDT, Singapore) and reconstituted in $10 \mathrm{mM}$ PBS buffer (pH 7.4). Aptamers were renatured using a Bio-Rad DNA engine thermocycler (Bio-Rad, Singapore) by heating to $94{ }^{\circ} \mathrm{C}$ for 10 minutes and then cooling down to room temperature at rate of $0.5^{\circ} \mathrm{C} / \mathrm{s}$. $10 \mathrm{mM}$ Tris- $\mathrm{HCl}$ buffer $(\mathrm{pH} 7.2)$ was used and all other reagents were of analytical reagent grade. The water used was purified through a Millipore system.

FAM-Aptamer: 5'-CTT CTG CCC GCC TCC TTC CGA CCT AGC AGT GGA CAT GTG GCA GGG TGA AGT GGC ATC GTC GGA GAC GAG ATA GGC GGA CAC T-3’

\section{Synthesis of polydopamine}

PDAs were synthesized according to previous reported method [14] with some modification. $100 \mathrm{~mL}$ of Tris-buffer solution was mixed with $40 \mathrm{~mL}$ of isopropyl alcohol (IPA). Then, $120 \mathrm{mg}$ of dopamine hydrochloride was added to the mixed solution. Finally, PDA spheres (PDAs) can be obtained after polymerization under stirring for about 60 
hours. The suspension was centrifuged, washed and re-suspended with water for several times. The precipitate was dried in vacuum for sensing experiments. Characterization of PDAs was performed by SHIMADZU IR Prestige21 spectrophotometry for the Fourier transform infrared (FTIR, Japan) and JEOL JSM-6701F Field Emission Scanning Electron Microscope (FESEM, Japan), respectively.

\section{Quenching and detection process}

The fluorescence emission spectrum was recorded for quenching and detection process with a Gilden Photonics FluoroSENS Fluorometer (United Kingdom). The emission spectra were recorded from 500 to $650 \mathrm{~nm}$ at an excitation wavelength of $470 \mathrm{~nm}$, and the fluorescence intensity at $517 \mathrm{~nm}$ was used for quantitative analysis. For the quenching process, FAM-aptamer $(40 \mathrm{nM})$ was incubated with PDAs at different concentration for 10 min at room temperature before the fluorescent detection. Then different amount of concentrated catalase solution $(2 \mu \mathrm{M})$ was added to make $\mathrm{BCP}$ at $10,20,50,100,200,500$ and $1000 \mathrm{nM}$ in the mixtures for detection process respectively. After a gentle mixing, the mixtures were allowed to incubate for 1 hour at $37{ }^{\circ} \mathrm{C}$ before the fluorescence measurement.

\section{The sensing scheme of the platform}

\section{Results and Discussion}

The principle of nanomaterial quenching and sensing is shown in Figure 1. 6-carboxyfluorescein (FAM), labelled the aptamer at the 5' end, has strong fluorescence emission. Free fluorophore labelled ssDNA aptamer possess a strong fluorescence emission in the presence of the fluorescein-based dye. PDAs include dihydroxyindole, indoledione, and dopamine units. The interaction between PDAs and ssDNA might be non-covalent binding due to hydrogen bonding, $\pi-\pi$ stacking, or charge-transfer complexes between the units of PDA and nucleobases $[8,15$, 16]. Thus the introduction of PDAs would result in binding with probe ssDNA to form a complex, resulting in quenching process of the fluorescence due to FRET between PDAs and the fluorescent dye FAM. However, the complementary interaction between protein and aptamer will induce the conformation of aptamer upon the introduction of targets. In consequence, fluorophore labelled aptamer would release from surface of PDAs due to the weakened interaction between them, leading to the recovery of the fluorescence. Hence, the restoration of fluorescence can be applied to the quantitative analysis of target DNA or toxin protein.

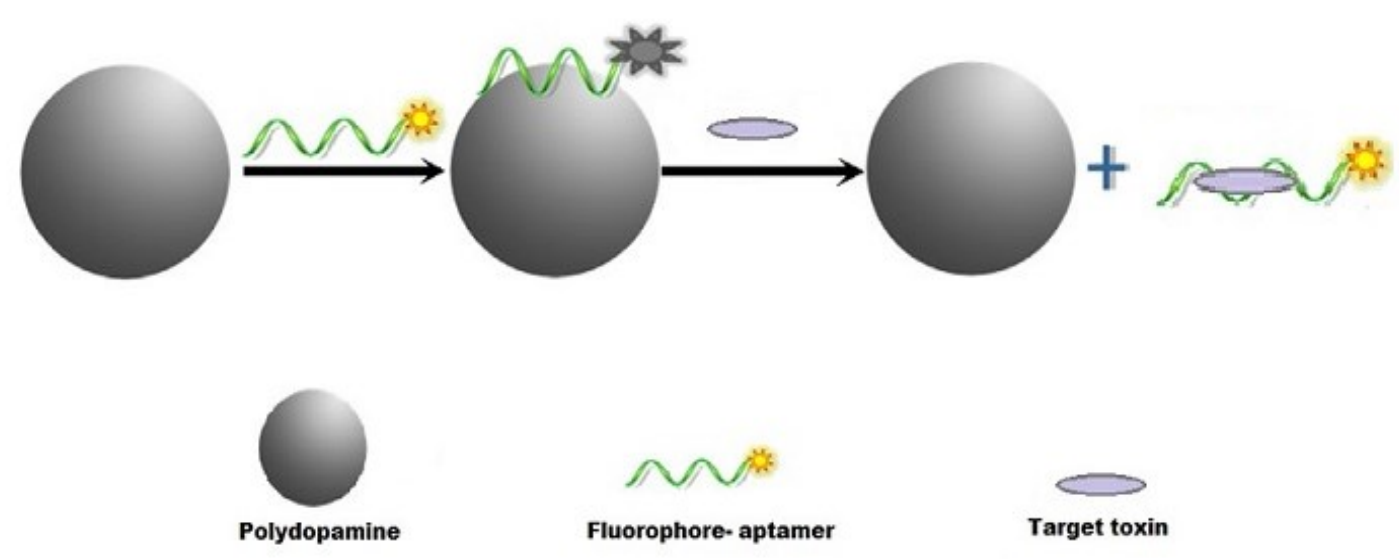

Figure 1. The principle of the sensing of protein

\section{Characterization of PDAs}

PDA spheres were synthesized in presence of IPA. The morphology and particle size of PDA spheres were characterized by FESEM, shown in Figure 2a. It could be found the size of the obtained PDA spheres is in the $250-$ $300 \mathrm{~nm}$ range. The FTIR spectrum of PDAs, shown in Figure $2 \mathrm{~b}$, gives the characteristic peaks of several functional groups, such as $\mathrm{C}=\mathrm{O}\left(\sim 1625 \mathrm{~cm}^{-1}\right), \mathrm{C}=\mathrm{C}\left(\sim 1521 \mathrm{~cm}^{-1}\right)$ and $\mathrm{C}-\mathrm{O}\left(\sim 1280 \mathrm{~cm}^{-1}\right)$, which also indicate that PDA is a $\pi$ - 


\section{Li \& Li: DETECTION OF BIOMOLECULES BY A NOVEL FLUORESCENCE APTASENSOR BASED ON POLYDOPAMINE SPHERES}

rich polymer. The absorption band at $\sim 3400 \mathrm{~cm}^{-1}$ corresponds to the stretching vibrations of $-\mathrm{OH}$ and $\mathrm{N}-\mathrm{H}$ groups in the PDAs.
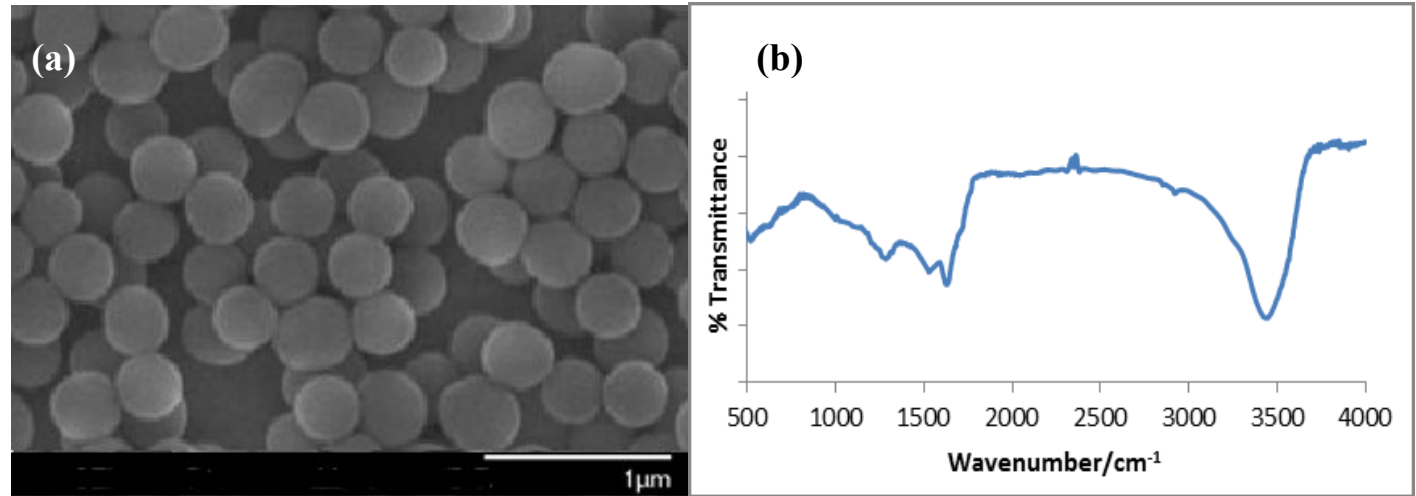

Figure 2. Characterization of PDAs. (a) SEM image and (b) FTIR spectra

\section{Quenching efficiency}

The feasibility of using PDA as nanoquencher for protein detection was explored. The fluorescence quenching abilities of the PDAs to the FAM-labelled aptamer were evaluated by measurements mixture of aptamer with the PDAs after incubation for $10 \mathrm{~min}$. As shown in the Figure 3a, the emission fluorescence of FAM-aptamer was partly quenched as the introduction of the PDAs. Quenching efficiency (QE) could be calculated as shown in equation 1:

$$
\frac{(\mathrm{FLo}-\mathrm{FLr})}{\mathrm{FLo}} \times 100 \%
$$

where $\mathrm{FL}_{\mathrm{o}}$ and $\mathrm{FL}_{\mathrm{r}}$ are fluorescence intensities without and with PDAs, respectively. Quenching efficiency increased with the increasing concentration of PDAs due to complex formation of FAM-Aptamer-PDAs. After PDAs was more than $0.2 \mathrm{mg} / \mathrm{mL}$, the quenching efficiency was more than $90 \%$ (Figure $3 \mathrm{~b}$ ) and almost consistent with more PDAs. Thus, $0.2 \mathrm{mg} / \mathrm{mL}$ was used for further sensing tests.

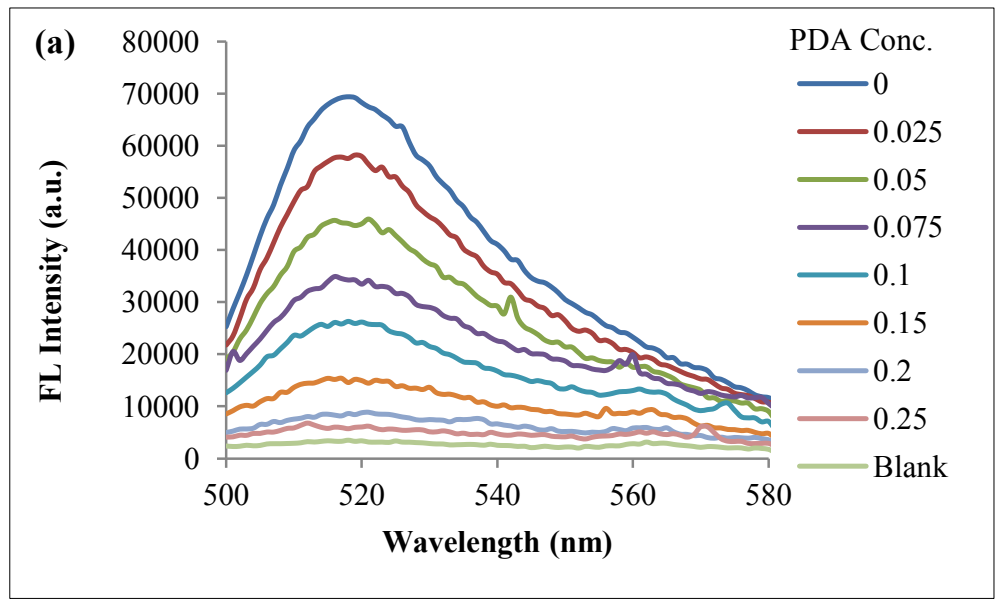




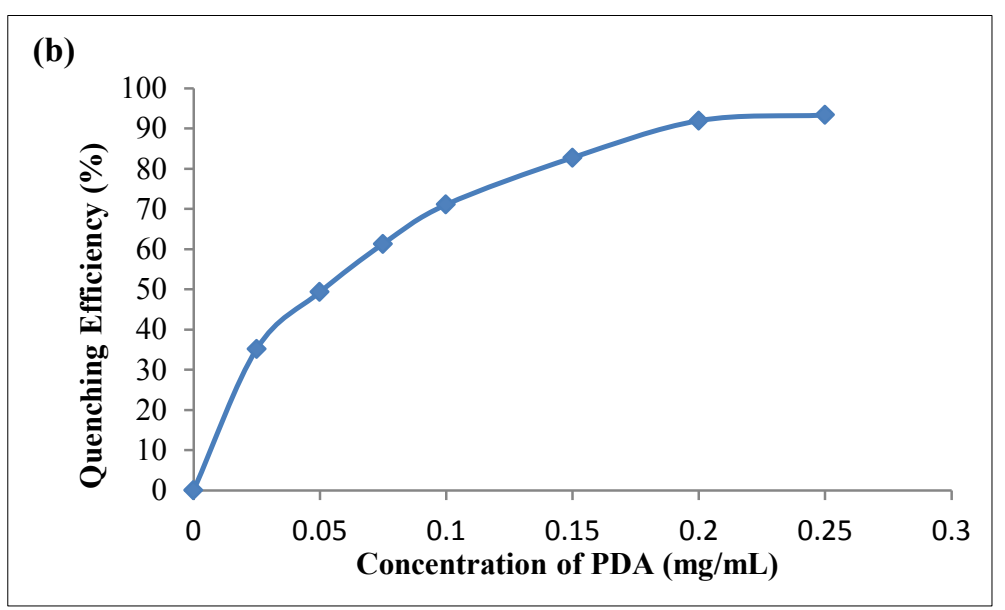

Figure 3. (a) Fluorescence spectra and (b) Quenching efficiency of FAM-aptamer with different concentrations of PDAs

\section{Detection process}

Fluorescence recovery was observed after the introduction of BCP with incubation time for 1 hour. Figure 4a shows the fluorescence emission spectra of FAM-Aptamer-PDAs in the presence of different concentrations of target. It could be found that more FAM-Aptamer was released which resulting in retained fluorescence with increasing concentration of BCP. By calculating difference of fluorescence intensity in presence and absence of $\mathrm{BCP}$, the calibration curve can be given as shown in Figure $4 \mathrm{~b}$. A dynamic range of $10-1000 \mathrm{nM}$ was established based on the fluorescence intensity. The limit of BCP detection was estimated to be $10 \mathrm{nM}$. The relative standard deviation is less than $10 \%$, which exhibits the reproducible results for this detection system. However, the recovery of fluorescence was not high though high concentration of BCP was added which may be caused by affinity problems of aptamer to target or short incubation time for releasing. The further optimization for the detection process would facility the improvement on sensitivity and accuracy.

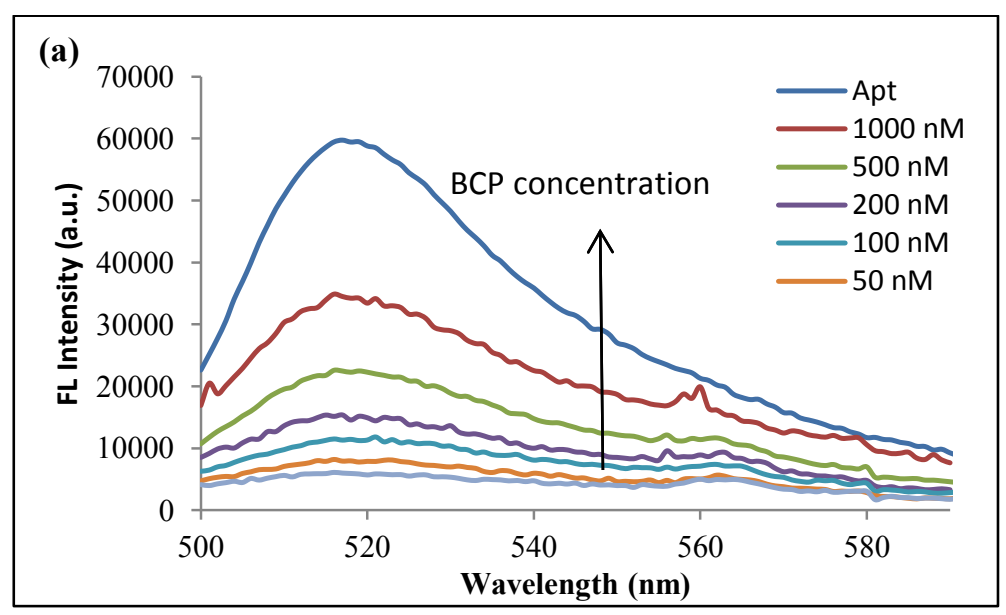




\section{Li \& Li: DETECTION OF BIOMOLECULES BY A NOVEL FLUORESCENCE APTASENSOR BASED ON POLYDOPAMINE SPHERES}

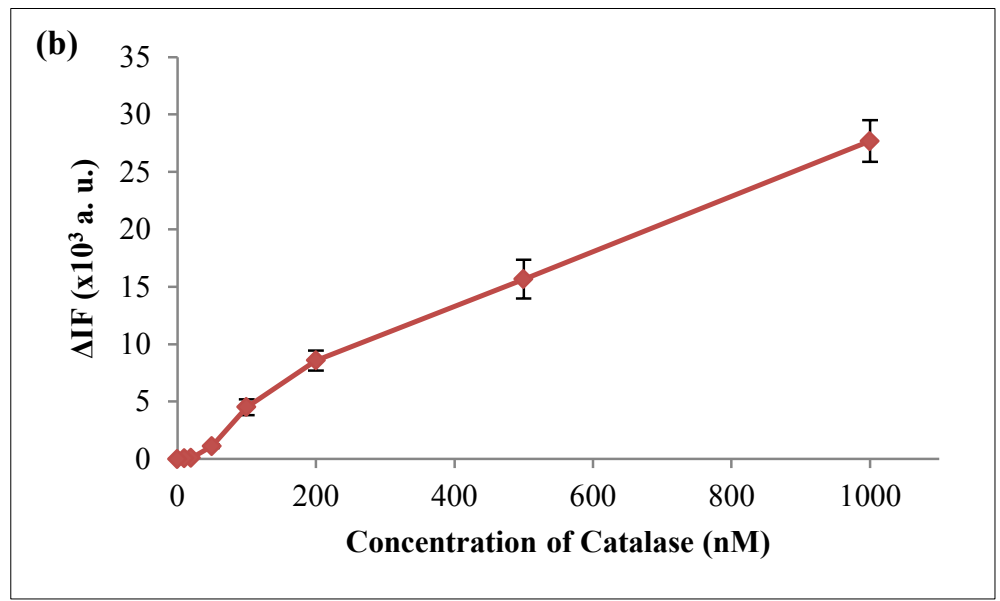

Figure 4. Fluorescence spectra (a) and calibration curve (b) for the FAM-Aptamer-PDAs in the presence of different concentrations of target BCP. Error bars are standard deviation from triplicates trial

\section{Conclusion}

In summary, a fluorescence aptasensor has been developed by taking advantage of specific aptamer and polydopamine sensing platform. It was found that the quenching efficiency was good (>90\%) owing to the interaction between FAM-aptamer and PDAs. The retained fluorescence intensity increased with the increasing concentration of target $\mathrm{BCP}$. The detection limit was confirmed at $10 \mathrm{nM}$. Further optimization of detection conditions may help to improve sensitivity. Some characterization of the developed sensor, such as interference effect by other compounds, would be performed in further study. PDAs could be used as sensing platform in fast and simple way for proteins detection and have potential to be extended to other targets.

\section{References}

1. Chelikani, P., Fita, I. and Loewen, P. C. (2004). Diversity of structures and properties among catalases. Cellular and Molecular Life Sciences, 61(2): 192 - 208.

2. Hulanicki, A., Glab, S. and Ingman, F. (1991). Chemical sensors: Definitions and classification. Pure and Applied Chemistry, 63(9): 1247 - 1250.

3. Aragay, G., Pino, F. and Merkoçi, A. (2012). Nanomaterials for sensing and destroying pesticides. Chemical Reviews, 112(10): 5317 - 5338.

4. Dubertret, B., Calame, M. and Libchaber, A. J. (2001). Single-mismatch detection using gold-quenched fluorescent oligonucleotides. Nature Biotechnology, 19(4): 365 - 370.

5. Yang, R., Jin, J., Chen, Y., Shao, N., Kang, H., Xiao, Z., Tang, Z. W., Wu, Y. R., Zhu, Z. and Tan, W. H. (2008). Carbon nanotube-quenched fluorescent oligonucleotides: Probes that fluoresce upon hybridization. Journal of the American Chemical Society, 130(26): 8351 - 8358.

6. Lu, C. H., Yang, H. H., Zhu, C. L., Chen, X. and Chen, G. N. (2009). A graphene platform for sensing biomolecules. Angewandte Chemie, 121(26): 4879 - 4881.

7. Duan, Y. F., Ning, Y., Song, Y. and Deng, L. (2014). Fluorescent aptasensor for the determination of Salmonella typhimurium based on a graphene oxide platform. Microchimica Acta, 181(5-6): 647 - 653 .

8. Qiang, W., Li, W., Li, X., Chen, X. and Xu, D. (2014). Bioinspired polydopamine nanospheres: A superquencher for fluorescence sensing of biomolecules. Chemical Science, 5(8): 3018 - 3024.

9. Liu, Q., Pu, Z., Asiri, A. M., Al-Youbi, A. O. and Sun, X. (2014). Polydopamine nanospheres: A biopolymerbased fluorescent sensing platform for DNA detection. Sensors and Actuators B: Chemical, 191: $567-571$.

10. Li, H., Zhang, Y., Wang, L., Tian, J. and Sun, X. (2011). Nucleic acid detection using carbon nanoparticles as a fluorescent sensing platform. Chemical Communications, 47(3): $961-963$.

11. Ji, X., Palui, G., Avellini, T., Na, H. B., Yi, C., Knappenberger Jr, K. L. and Mattoussi, H. (2012). On the pHdependent quenching of quantum dot photoluminescence by redox active dopamine. Journal of the American Chemical Society, 134(13): 6006 - 6017. 
12. Liu, Y., Ai, K. and Lu, L. (2014). Polydopamine and its derivative materials: Synthesis and promising applications in energy, environmental, and biomedical fields. Chemical Reviews, 114(9): $5057-5115$.

13. Ashley, J., Ji, K. and Li, S. F. (2012). Selection of bovine catalase aptamers using non - SELEX. Electrophoresis, 33(17): $2783-2789$.

14. Yan, J., Yang, L., Lin, M. F., Ma, J., Lu, X. and Lee, P. S. (2013). Polydopamine spheres as active templates for convenient synthesis of various nanostructures. Small, 9(4): $596-603$.

15. d'Ischia, M., Napolitano, A., Pezzella, A., Meredith, P. and Sarna, T. (2009). Chemical and Structural Diversity in Eumelanins: Unexplored Bio-Optoelectronic Materials. Angewandte Chemie International Edition, 48(22): $3914-3921$.

16. Varghese, N., Mogera, U., Govindaraj, A., Das, A., Maiti, P. K., Sood, A. K. and Rao, C. N. R. (2009). Binding of DNA nucleobases and nucleosides with graphene. ChemPhysChem, 10(1): 206 - 210. 